\title{
Pemberdayaan Bagi Masyarakat Terdampak Penutupan Lokalisasi Dolly Dengan Pelatihan Desain Dan Sablon Tas Belanja
}

\author{
Nurina Orta D, Octaviyanti Dwi W, Waluyohadi, Putri Dwitasari \\ Fakultas Teknik Sipil dan Perencanaan, Jurusan Desain Produk Industri, Institut Teknologi Sepuluh Nopember \\ nurinaorta@gmail.com
}

\begin{abstract}
Abstrak
Sebagai tindak lanjut atas penutupan Dolly, Pemerintah Kota Surabaya telah memberikan kompensasi 5,05 juta rupiah kepada setiap warga yang terkena dampak penutupan lokalisasi. Uang tersebut diberikan dalam bentuk tabungan, sebagian untuk modal usaha dan sebagian untuk bekal hidup sementara hingga penerima santunan bisa bekerja lagi. Selain bantuan berupa dana, bantuan berupa pelatihan keterampilan seperti membuat kue kering, telor asin, deterjen atau sabun cair juga dilakukan. Pendampingan dari mulai pelatihan hingga pemasaran produk sudah dilakukan. Setahun setelah Dolly ditutup, memang beberapa warga mulai beralih ke usaha baru hasil pelatihan, seperti berdagang telur asin atau membuat sabun deterjen yang dijual ke binatu. Pemerintah Kota Surabaya berusaha menjadikan Dolly dan warganya sebagai wilayah usaha ekonomi produktif.
\end{abstract}

Surabaya sejak awal tahun 2016 sedang berusaha mensosialisasikan bahaya dan kerugian menggunakan kresek plastik untuk berbelanja. Bukti partisipasi ini adalah dikenakannya biaya untuk penggunaan kantong plastik atau mengganti penggunaan kantong dengan kardus bekas di banyak minimarket dan supermarket di Surabaya. Hal tersebut mengharuskan para pelanggan membawa sendiri kantong belanja dari rumah, dengan tujuan mengurangi angka penggunaan kantong plastik di Surabaya. Fenomena tersebut membuat peluang tersendiri bagi industri tas sablon untuk berkembang, karena permintaan akan tas yang bisa digunakan lagi (reusable bags) akan semakin meningkat. Peningkatan keterampilan masyarakat untuk mendorong kemandirian merupakan bagian penting dalam rangka mengurangi pengangguran dan kemiskinan terutama di Dolly. Jenis pelatihan yang dilakukan berupa latihan desain, sablon dan jahit tas belanja berbagai macam bahan, selain untuk suvenir juga dapat digunakan sebagai pengganti tas plastik untuk berbelanja dengan desain yang beraneka rupa dan mengangkat beragam tema.

Keyword: Pelatihan sablon, jahit, tas belanja, dolly

\section{PENDAhuluan}

Surabaya sebelum tahun 2014 memiliki sebuah lokalisasi terbesar di Asia-tenggara, dikenal dengan sebutan Dolly. Tahun 2014 lokalisasi ini ditutup oleh Pemerintah Kota Surabaya. Penutupan ini menimbulkan berbagai dampak, utamanya dampak ekonomi, sebab Dolly adalah sebuah sentra ekonomi yang dijadikan sumber mata pencaharian bukan hanya bagi para pekerja seks komersial saja, tapi bagi penjaja makanan, pemilik warung hingga tukang parkir yang mencari nafkah harian di tempat tersebut.

Dari data yang diperoleh, ada sekitar 1400 orang pekerja seks komersial yang beroperasi setiap harinya di Dolly. Selain para PSK yang menjadi pusat perputaran ekonomi, diestimasikan ada 14.000 orang dari seluruh Indonesia yang menggantungkan hidupnya dari Dolly dengan berbagai profesi (Anissa, dari Indonesia's Independent Youth Community (KOPI) organization). Penutupan Dolly yang dilakukan oleh pemkot tentu akan berdampak luar biasa bagi mereka. Mayoritas PSK yang berada di Dolly sudah bekerja bertahun-tahun, menjadi tulang punggung keluarga dan mayoritas berpendidikan rendah. Pendapatan bulanan para PSK dan masyarakat bisa mencapai 15 juta rupiah perbulan, dan penutupan oleh pemerintah akan sangat menurunkan pemasukan mereka.

Sebagai tindak lanjut atas penutupan Dolly, Pemerintah Kota Surabaya telah memberikan kompensasi 5,05 juta rupiah kepada setiap warga yang terkena dampak penutupan lokalisasi. Uang tersebut diberikan dalam bentuk tabungan, sebagian untuk modal usaha dan sebagian untuk bekal hidup sementara hingga penerima santunan bisa bekerja lagi. Untuk PSK luar daerah uang tersebut juga digunakan untuk biaya pulang ke daerah asal. Selain biaya transportasi, bagi warga terdampak uang itu diharapkan dapat menjadi modal usaha yang dapat menjadi penghasilan pengganti bagi mereka kelak.

Selain bantuan berupa dana, bantuan berupa pelatihan keterampilan seperti membuat kue kering, telor asin, deterjen atau sabun cair juga dilakukan. Pendampingan dari mulai pelatihan hingga pemasaran produk sudah dilakukan. Pemberdayaan warga terdampak seperti menjadikan mereka pengusaha pulsa atau travel agent, hingga mengangkat warga menjadi tenaga di pemerintahan juga dilakukan. Setahun setelah Dolly ditutup, memang beberapa warga mulai beralih ke usaha baru hasil pelatihan, seperti berdagang telur asin atau membuat sabun deterjen yang dijual ke binatu. Pemerintah Kota Surabaya berusaha menjadikan Dolly dan warganya sebagai wilayah usaha ekonomi produktif.

Surabaya sejak awal tahun 2016 sedang berusaha mensosialisasikan bahaya dan kerugian menggunakan kresek plastik untuk berbelanja. Bukti partisipasi ini adalah dikenakannya biaya untuk penggunaan kantong plastik atau mengganti 
pepenggunaan kantong dengan kardus bekas di banyak minimarket dan supermarket di Surabaya. Hal tersebut mengharuskan para pelanggan membawa sendiri kantong belanja dari rumah, dengan tujuan mengurangi angka penggunaan kantong plastik di Surabaya. Fenomena tersebut membuat peluang tersendiri bagi industri tas sablon untuk berkembang, karena permintaan akan tas yang bisa digunakan lagi (reusable bags) akan semakin meningkat. Peningkatan ketrampilan masyarakat untuk mendorong kemandirian merupakan bagian penting dalam rangka mengurangi pengangguran dan kemiskinan di Dolly. Jenis pelatihan yang dilakukan berupa latihan desain, sablon dan jahit tas belanja berbagai macam bahan, selain untuk suvenir juga dapat digunakan sebagai pengganti tas plastik alternatif dengan berbagai warna, motif dan tema. Pada pelaksanaannya disisipkan sedikit materi tentang modal dan pemasan sebagai pengantar peserta jika ingin memulai suatu usaha.
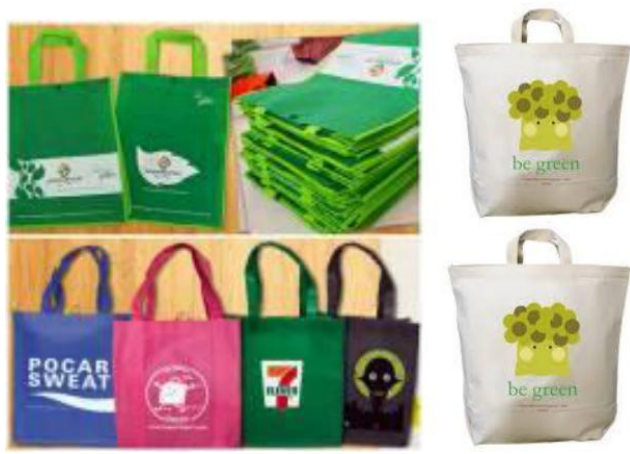

Gambar 1.1 : Contoh Sablon Re-usable Bag untuk Berbelanja [1]

Permintaan akan sablon tas belanja sangat tinggi di perkotaan, dikarenakan banyaknya pusat belanja dan aktifitas jual beli yang terjadi setiap harinya. Pengerjaan sablon tas biasanya dilakukan secara manual, oleh karena itu tingginya permintaan dan kapasitas menyebabkan waktu pengerjaan menjadi lama. Tas jenis ini memiliki aneka pilihan bahan, yang paling banyak digunakan untuk disablon adalah tas plastik, tas polyester, tas kanvas dan tas spundbund. Biasanya tas tersebut selain digunakan untuk pengemas setelah belanja juga dipakai untuk event, karena sifat tas yang dapat disablon sehingga dapat memuat identitas atau desain yang diinginkan. Seringkali tas sablon juga digunakan sebagai suvenir, karena desain dan bentuknya yang unik dan variatif.

Usaha-usaha pelatihan yang dilakukan oleh Pemerintah Kota Surabaya selama setahun ini menjangkau sekitar 600 orang warga yang terkena dampak penutupan (Dedy Listiadi, Kepala dinsos Surabaya). Jumlah ini tentunya masih sangat kecil melihat data sebelumnya, bahwa 14.000 orang butuh pekerjaan baru setelah Dolly ditutup. Sisanya tentu masih membutuhkan perhatian pemerintah, bantuan pelatihan, karena minimnya pendidikan dan keterampilan yang dimiliki masyarakat terdampak. Menurut (1990, 63), pelatihan berarti menuntun dan mengarahkan perkembangan dari peserta pelatihan melalui pengetahuan, keahlian dan sikap yang diperoleh untuk memenuhi standar tertentu.

\section{TINJAUAN PUSTAKA}

\section{Kajian Desain Tas Belanja}

ECO BAG atau sering juga disebut MY BAG ini adalah tas belanja yang bisa dipakai berkali-kali, bisa berbahan kain, plastik atau apa saja. Jenis tas ini terispirasi dari kebudayaan Jepang yang konsen terhadap Tas belanja ekonomis, dapat disimpan, dilipat dan digunakan lagi saat hendak belanja. Jenis bahan-bahan yang digunakan adalah polyester, spudbundt, katun, blacu dll. Penggunaan tas ini dapat menghemat pengeluaran biaya kantong kresek dan sangat teramat ramah lingkungan.
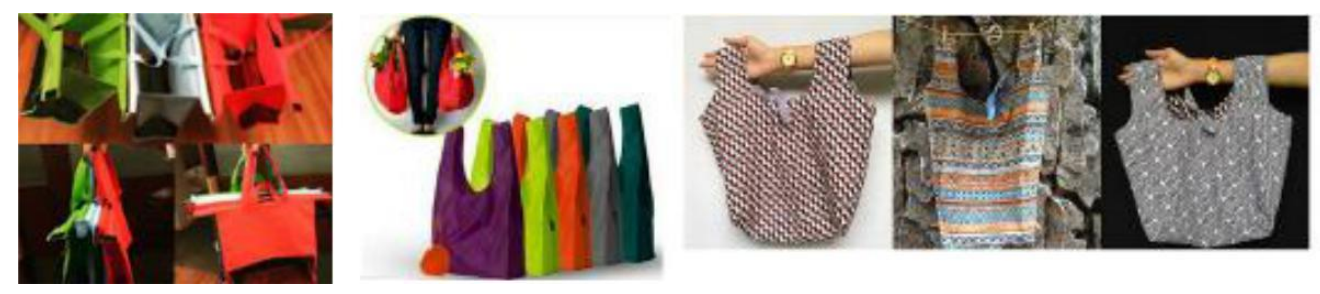

Gambar 2.1 Jenis-tas belanja ramah lingkungan [1]

\section{Kajian Teknik Sablon (Cetak Saring)}

Sablon (Silkscreen Printing) merupakan salah satu teknik cetak yang cukup berkembang dimasyarakat. Hampir disetiap sudut dapat kita jumpai orang yang menawarkan jasa sablon. Hal ini pertanda bahwa sablon merupakan usaha yang cukup menguntungkan dan memiliki pangsa pasar yang luas sehingga persaingan cukup ketat disektor ini. Andrews (1964) menguraikan bahwa teknik silk screen dan Serigraphy merupakan cetak saring yang sederhana (simple silk screen printing) dan cetak saring lanjutan (advanced silk screen printing). Teknik cetak saring sederhana ini diantaranya dilakukan dengan teknik paper cut (melubangi bagian kertas sebagai bahan acuan gambar). Teknik cetak saring lanjutan terdiri dari 1) Paper block out; 2) crayon block out; 3) Lacquer film block-out; 4) Tusache block-out; dan 5) Glue block-out. Pendapat yang sama dikemukakan Caza (tanpa tahun : 27-38) menjelaskan lima teknik penggambaran pada screen, yaitu: Line work and flat colour; 2) Block out ; 3) Drawing with seroid; 4) Drawing with litho ink; dan 5) The Mercier Method. 


\section{METODE PENELITIAN}

Pelatihan ini akan dilakukan dengan 4 tahap, yakni:

- Pelatihan Jahit

Materi yang diberikan meliputi jenis bahan dan peralatan, membuat 2 pola tas belanja, memotong kain, teknik menjahit tas dengan benar, finishing

- Pelatihan Desain

Materi yang disampaikan adalah pengetahuan desain pada tas belanja populer yang beredar, berikut aplikasinya menggunakan Corel Draw, meliputi desain Tas Belanja, Praktek membuat desain sederhana dengan perangkat lunak CorelDraw

- Pelatihan Sablon

Materi yang diberikan adalah cara teknis sablon manual untuk pemula, meliputi membuat mal/master desain, Jenis bahan dan peralatan, finishing

- Pelatihan Modal dan Pemasaran

Materi ini untuk memberikan bekal pengelolaan usaha, materi yang diberikan secara sederhana sesuai kebutuhan usaha yang di laksanakan oleh peserta, meliputi Fungsi Manajemen, Manajemen Pemasaran, Manajemen Keuangan dan Produksi

\section{HASIL DAN PEMBAHASAN}

Pelatihan ini bekerja sama dengan pihak Badan Pengembangan Masyarakat dan Keluarga Berencana (Bappemas-KB) Pemerintah Kota Surabaya untuk mengidentifikasi dan menseleksi calon peserta pelatihan. Kegiatan pelatihan dilaksanakan di Kantor Kelurahan Putat Jaya, Kecamatan Sawahan, Surabaya. Dipilihnya lokasi ini karena daerah terdampak merupakan cakupan wilayah Kelurahan Putat Jaya. Selain itu, Kantor Kelurahan Putat Jaya memiliki fasilitas yang ideal berupa ruang kelas, Joglo pelatihan, Broadband Learning Center dengan 10 unit komputer dan pendapa yang bisa digunakan sebagai workshop praktek sablon.

Kegiatan PPM Pemberdayaan Masyarakat terdampak penutupan lokalisasi Dolly dilaksanakan dalam jangka waktu tiga hari mulai tanggal $2-4$ Agustus 2016. Tujuan utama pelatihan ini agar para peserta mengerti dan memahami tentang bagaimana memproduksi tas belanja dari mulai membeli bahan hingga ke tangan konsumen.

\section{A. Hari Pertama}

Setelah registrasi, peserta diberikan 1 tas berisi gunting, pensil, bolpen, penghapus, penggaris, pemotong kertas, kertas karton ukuran A2, Name Tag, 2 lembar kain berukuran masing masing 1 meter (kain paying/parasut), tali, pita, benang, resleting, pengait untuk tas, kertas buram. Paket tas ini nantinya akan dibawa peserta selama 3 hari pelatihan. Materi yang disampaikan adalah material tas belanja, pengetahuan dasar pola, praktek membuat pola dasar 2 jenis model tas belanja, mengaplikasikan pola pada bahan kain, memotong pola dengan baik, menjahit tas. Materi tentang modal dan pemasaran sederhana juga disampaikan untuk memberikan bekal pengelolaan usaha serta sesuai kebutuhan usaha yang di laksanakan oleh peserta, meliputi Fungsi Manajemen, Manajemen Pemasaran, Manajemen Keuangan dan Produksi. Materi ini diberikan agar peserta mengerti bagaimana mengelola modal dan bagaimana memasarkan setelah mereka memproduksi tas belanja.

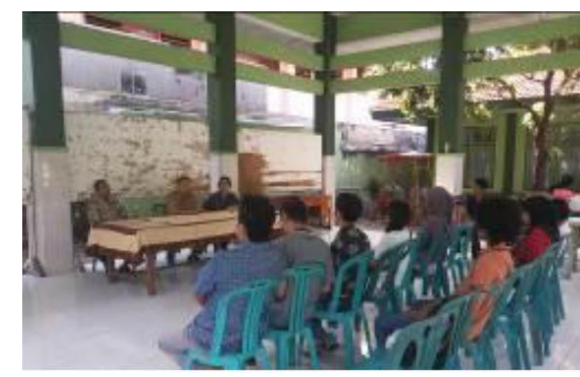

Gambar 4.1 Pembukaan Pelatihan oleh Ketua Pengabdi dan Sekretris Lurah Putat Jaya, Bapak Wahyu Iswara

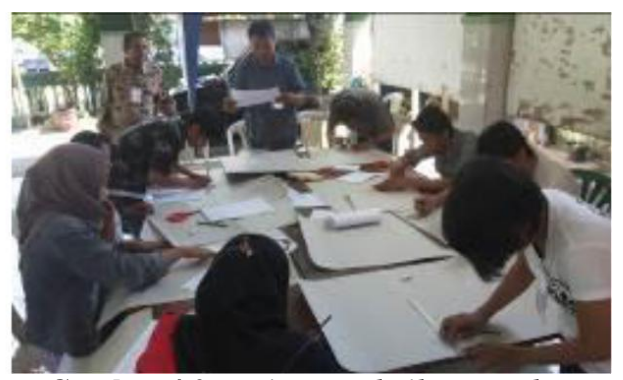

Gambar 4.2 Kegiatan Pelatihan Pembuatan Pola 


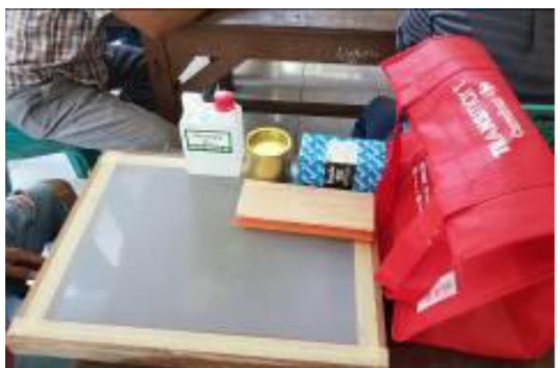

Gambar 4.3

Paket yang didapatkan oleh peserta pelatihan
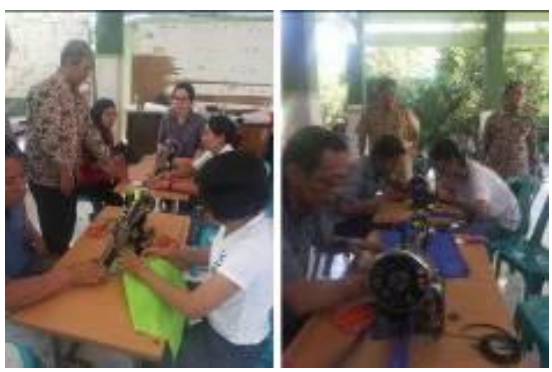

Gambar 4.5

Kegiatan Pelatihan Menjahit

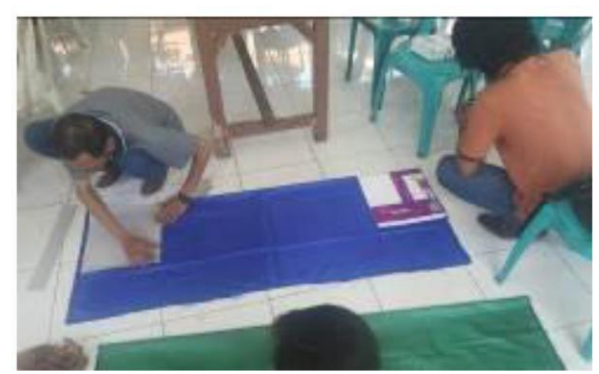

Gambar 4.2 Kegiatan Pelatihan Pembuatan Pola

\section{B. Hari Kedua}

Peserta melanjutkan kegiatan menjahit untuk model tas kedua. Setelah semua model tas telah jadi, kegiatan berikutnya dilanjutkan dengan pelatihan menyablon ke 2 model tas yang telah dijahit. Sebelumnya, sebagai pembuka diberikan materi tentang pengetahuan desain pada tas belanja populer yang beredar, berikut aplikasinya menggunakan Corel Draw. Untuk pelatihan sablon, peserta mendapatkan sejumlah peralatan berupa screen, rakel, tinta, film untuk cetak dan cairan afdruk.

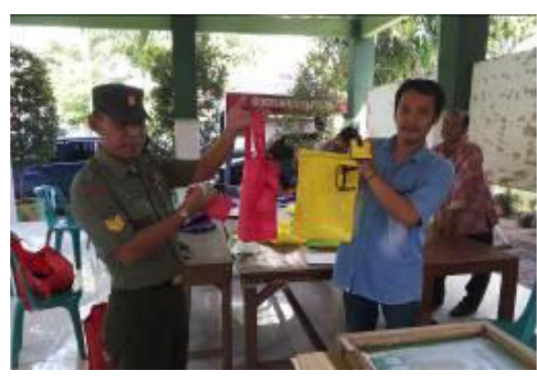

Gambar 4.5

Hasil tas belanja yang telah dijahit

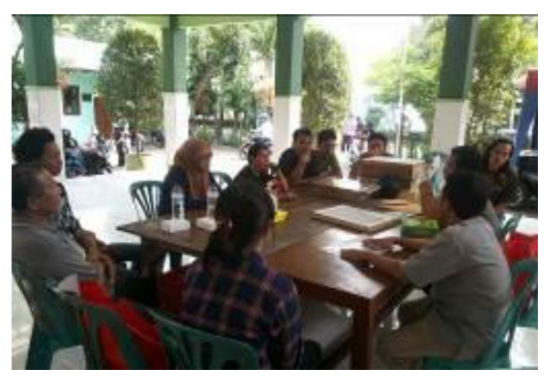

Gambar 4.5

Kegiatan Pelatihan Menyablon

Peserta mulai dengan membuat film / afdruk gambar (pemindahan gambar dari kertas ke screen sablon) dengan bantuan obat sablon. Proses ini dilakukan di dalam ruang dengan pencahayaan rendah. Setelah menunggu beberapa saat, peserta menyiapkan screen dan mencoba aplikasi sablon manual menggunakan rakel, cat serta menempatkan kain tas dengan tepat dan presisi. Pada hari ke dua pelatihan, peserta juga mendapatkan materi pengantar tentang desain tas belanja dan berbagai aplikasinya.

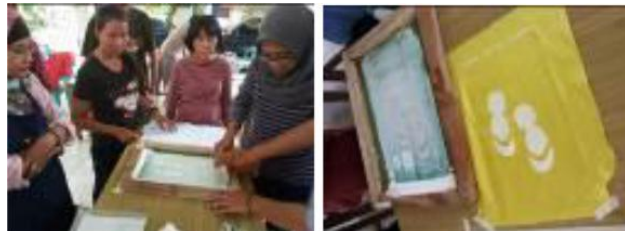

Gambar 4.5

Proses Menyablon

\section{Hari Ketiga}

Pelatihan hari ketiga peserta menyempurrnakan hasil tas, mulai dari memperhalus jaitan yang kasar sampai pada pembersihan bekas sablon. Kegiatan hari ketiga juga diisi dengan pelatihan penghitungan modal yang disampaikan oleh kedua narasumber. 

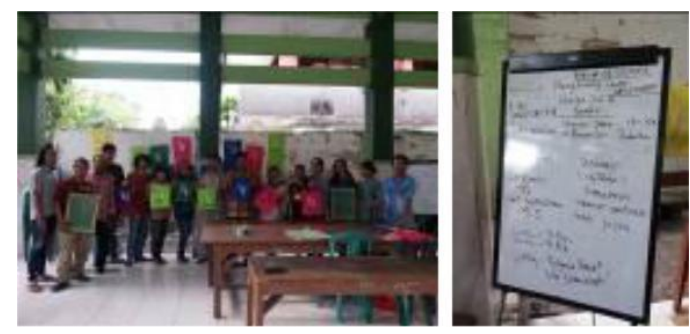

Gambar 4.5

Pelatihan hari ke 3

\section{KESIMPULAN}

Diharapkan setelah melakukan pelatihan selama tiga hari, peserta mulai memahami tahap-tahap dari proses bisnis tas belanja. Peserta juga dapat memahami proses produksi. Masing-masing pelatihan membutuhkan ketelatenan bagi pelakunya karena membuat tas belanja bukan hal yang mudah, selain memerlukan keterampilan juga membutuhkan ide kreatif untuk model dan desainnya. Setelah selesai pelatihan, peserta masih membutuhkan banyak latihan agar terbiasa terutama pada proses menjahit terutama jika mereka memang ingin mendalami bidang usaha ini. Instruktur pelatihan dapat berfungsi sebagai tempat magang dan latihan lanjutan apabila peserta ingin lebih belajar.

Pelatihan yang berkelanjutan akan memberi bekal kepada masyarakat terdampak untuk merintis kampung sablon. Di Bandung terdapat kampung sentra usaha produksi kaos, dimana lini produksi mulai dari hulu sampai hilir diadakan di satu lokasi saja, sehingga kampung clothing ini juga menjadi tujuan utama para pengusaha clothing di luar Bandung. Di Magelang terdapat kampung desainer dan kampung blogger, dimana warga dikampung tersebut diajari cara membuat desain grafis dan logo dengan menggunakan software corel dan photoshop. Di Klaten terdapat paguyuban kampung sablon, Paguyuban ini adalah Organisasi Rakyat yang bersifat non partisan, independent dan nirlaba. Paguyuban Kampung Sablon yang berbasis keanggotaan di komunitas pemilik home industri dan pekerja konveksi di dukuh Krangkungan Pandes Wedi Klaten. Paguyuban Kampung Sablon adalah salah satu wadah sekaligus model pengembangan masyarakat berbasis pemberdayaan dan modal sosial. Dukuh Krangkungan sendiri sudah dikenal oleh masyarakat Klaten sebagai dukuh yang mayoritas warganya bermata pencaharian di bidang konveksi. Begitu pula dengan beberapa dukuh di sekitarnya, yaitu Dukuh Beji, Dalangan, Karang, dan Buntalan. Sementara, para pengusaha lokal Surabaya banyak menggunakan jasa sablon dari Jogjakarta sebagai sarana pemenuhan kebutuhan usaha mereka dikarenakan Surabaya tidak mampu menampung kebutuhan produksi.

Sehubungan dengan berbagai macam kelebihan tersebut, Usaha Desain, Sablon dan jahit Tas Belanja Surabaya ini dapat dikembangkan sebagai alternatif memberikan bekal kemandirian bagi masyarakat terdampak penutupan lokalisasi Dolly, guna memperoleh kesempatan kerja dan kesempatan berusaha dalam upaya mengentaskan pengangguran dan kemiskinan. Jenis Ketrampilan ini dapat dikembangkan disetiap daerah. Usaha ini bisa dilakukan dengan modal yang relatif ringan, dapat menyerap banyak tenaga kerja, dan dapat dikerjakan oleh laki-laki dan perempuan.

Pemberdayaan masyarakat dapat diartikan sebagai proses yang membangun masyarakat melalui pengembangan kemampuan, perubahan perilaku, dan pengorganisasian masyarakat. Prinsip dasar pemberdayaan masyarakat terdiri dari 5 tahapan, yaitu penyadaran, pelatihan, pengorganisasian, pengembangan kekuatan dan membangun sebuah dinamika. Penyadaran adalah bagaimana masyarakat bisa diajak untuk merubah hidupnya, hingga mereka memiliki aspirasi dan tujuan dalam hidup. Pelatihan adalah bagaimana mendidik masyarakat mengenai cara kerumahtanggaan, industri baik secara individu maupun kelompok, belajar dari sumber langsung tentang sebuah usaha dari hulu ke hilir. Pengorganisasian berarti adanya pembagian tugas dari sebuah kelompok masyarakat. Pengembangan kekuatan berarti bagaimana menginspirasi masyarakat, mencari badan atau organisasi yang dapat mendukung sehingga mereka semangat untuk maju. Dinamika adalah bagaimana masyarakat mampu mengelola sistemnya sendiri dan mengambil keputusan untuk dirinya sendiri.

\section{DAFTAR PUSTAKA}

"No Title." [Online]. Available: http://www.kompasiana.com/weedykoshino/eco-bag-tas-belanja-. 